\title{
ANALISIS STATUS EKSPLOITASI SUMBERDAYA PERIKANAN PROVINSI ACEH
}

\author{
Asmawati ${ }^{1}$ dan Muhammad Nasir ${ }^{2}$ \\ ${ }^{1)}$ Ilmu Ekonomi dan Studi Pembangunan, Fakultas Ekonomi, Universitas Abulyatama \\ Jl. Blang Bintang Lama Km 8,5 Lampoh Keude Aceh Besar, \\ email: asmawati@abulyatama.ac.id \\ ${ }^{2)}$ Agri Bisnis, Fakultas Pertanian, Universitas Abulyatama \\ Jl. Blang Bintang Lama Km 8,5 Lampoh Keude Aceh Besar.
}

\begin{abstract}
Fish commodities are a renewable resource and public property, whose utilization needs to be sustainable. This study aims to analyze the condition of the utilization of Aceh fishery resources, using a simple method of long-term fish supply curve, by assessing the relationship between production and price movement of fish. The 27-year time series data published by DKP has been used, in the form of production and price data. The results of the analysis indicate that the utilization has excessive exploitation for Malacca Strait fisheries, and less exploitation in the Indian Ocean region
\end{abstract}

Keywords : long-term offerings, sustainable, renewable resources, common property, fishery market data

\begin{abstract}
Abstrak: Komoditas ikan merupakan sumberdaya terbarukan dan milik umum, yang pemanfaatannya perlu dilakukan secara berkelanjutan. Studi ini bertujuan menganalisis kondisi pemanfaatan sumberdaya ikan di perairan Aceh, dengan menggunakan metode sederhana yaitu menggunakan kurva penawaran sumberdaya ikan jangka panjang, yang menilai hubungan antara produksi dan pergerakan harga ikan. Menggunakan data seri waktu selama 27 tahun yang dipublikan DKP, berupa data jumlah produksi dan harga. Hasil analisis menunjukkan bahwa pemanfaatan telah kelebihan eksploitasi untuk perikanan Selat Malaka, dan kurang eksploitasi pada wilayah Samudera Hindia.
\end{abstract}

Kata kunci : penawaran jangka panjang, berkelanjutan, sumberdaya terbarukan, milik umum, data pasar perikanan

Provinsi Aceh sebagai provinsi dengan garis pantai terpanjang di Pulau Sumatera memiliki potensi perikanan yang lebih besar dibandingkan daerah lainnya. Namun, kontribusi sektor perikanan Aceh terhadap PDRB relatif rendah yaitu hanya 4,94 persen pada tahun 2015. Disinyalir bahwa salah satu penyebab rendahnya kinerja sektor perikanan adalah karena terjadinya economic overfishing. (Indra, 2007) yang memfokuskan penilaian pada ikan pelagis, melaporkan bahwa perikanan Aceh telah mengalami kelebihan kapasitas dan perlu pengurangan effort dengan persentase lebih besar pada pantai barat yaitu dari $0-46,3 \%$, sedangkan di pantai timur dari 0-34,0\%. Kelebihan kapasitas diperkirakan terjadi pada perairan dekat pantai, mengingat bantuan pasca tsunami kepada para nelayan Aceh lebih fokus pada katagori kapal motor kecil (Tewfik, Andrew, Bene, \& Garces, 2008). Padahal 56 persen asupan protein 
masyarakat Indonesia berasal dari ikan dan/atau produk perikanan (Kelautan, 2006), sementara itu perikanan Aceh menjadi penyedia mata pencaharian secara langsung bagi lebih 16 persen penduduk pantai dan memainkan peranan penting untuk keamanan pangan dengan memberikan kontribusi lebih 50 persen kebutuhan protein hewani penduduk Aceh Aceh. (BRR, 2005).

Sesungguhnya, jika dikelola dengan baik, sumberdaya perikanan mampu berkontribusi dalam penyediaan lapangan kerja, dan keamanan pangan, terutama sebagai sumber protein hewani yang berkualitas. Terkait hal ini telah banyak studi yang dilakukan antara lain, $\left(\mathrm{Be}^{\prime} \mathrm{Ne}^{\prime}\right.$, et al., 2016), (Agus, Arifin, \& Harjito, 2008), (Briones, Garces, \& Ahmed, 2005), (Moreno \& Majkowski, 2005), (Nahib, 2007), (Muchaponwa, 2009), (Asmawati \& Nazamuddin, 2013), (Bischi, Kopel, \& Szidarovszky, 2005).

Pengetahuan terhadap kondisi pemanfaatan sumberdaya perikanan laut, menjadi penting guna menghindari diri dari pengambilan kebijakan yang misleading, mengingat dampak yang ditimbulkan akibat rusaknya sumberdaya ini sangat serius. Kollapsnya perikanan Cod di perairan Atlantik (Kanada) pada tahun 1990-an dapat dijadikan contoh, dengan dampak ekonomi yang paling parah bahkan menjadi mimpi buruk dalam sejarah Negeri Kanada (Walters \& Maguire, 1996). Disisi lain, membiarkan kelimpahan sumberdaya ikan, tidak dimanfaatkan dengan baik, juga akan sangat merugikan bagi kesejahteraan masyarakat.
Studi ini mengaplikasikan model bioekonomi untuk mengidentifikasi secara intensif status eksploitasi perikanan Aceh, dengan menggunakan data harga dan jumlah tangkapan (data pasar) sebagai indikator..

\section{KAJIAN PUSTAKA}

\section{Ikan merupakan sumberdaya dapat pulih}

Spesies ikan di laut apabila ditangkap dalam jumlah tertentu, maka dalam suatu periode dan kecepatan tertentu stok atau biomas yang telah berkurang tersebut dapat tumbuh kembali, untuk kemudian dipanen lagi, tumbuh lagi dan demikian seterusnya. Namun demikian, daya regenerasi stok ikan mempunyai keterbatasan, apabila penangkapan melebihi kapasitas untuk pulih maka stok akan berkurang menuju kepunahan. Inilah sifat yang paling esensial dari sumber daya terbarukan yaitu jumlah stok tidak tetap. Stok akan meningkat, jika stok diperbolehkan untuk berkembang biak (Pearce \& Turner, 1987).

Dinamisasi stok ikan dipengaruhi oleh dua hal. Pertama, populasi ikan dapat pulih, artinya mampu untuk bereproduksi antar waktu. Kedua, stok ikan dapat menurun akibat aktivitas nelayan yang menangkap dan menjualnya ke pasar (Bischi, Kopel, \& Szidarovszky, 2005). Populasi ikan akan mengikuti suatu kecenderungan tertentu sesuai dengan perubahan kondisi lingkungan, seperti iklim, suhu peraiaran (Briones, Garces, \& Ahmed, 2005).

Pertumbuhan sumberdaya perikanan bersifat dinamis. Hubunngan proporsional yang memperlihatkan ketergantungan antara tingkat 
kelahiran dengan besarnya populasi. Hubungan seperti ini selalu ditemukan dalam berbagai gejala kehidupan biologis. Pertumbuhan populasi ikan pada awalnya cukup cepat dengan tingkat pertumbuhan yang positif, ini didukung oleh ketersediaaan daya dukung lingkungan yang masih cukup tinggi. Setelah suatu titik pertumbuhan tertentu kemampuan daya dukung alam mulai menurun dan persaingan antar spesies itu sendiri semakin tinggi sehingga pertumbuhan ikan (dx/dt) semakin menurun atau tumbuh pada tingkat pertumbuhan negatif. Pada saat jumlah stok mencapai $X_{\max }$ pertumbuhan populasi mencapai nol, populasi tidak lagi berkembang, atau disebut mencapai carrying capacity (Gambar 1).

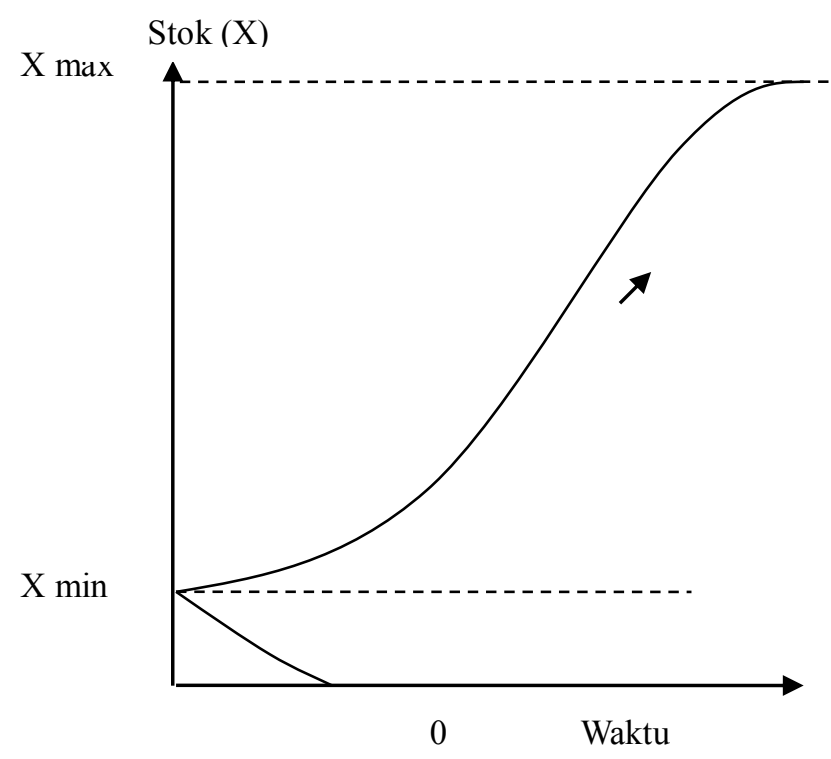

Gambar 1. Kurva pertumbuhan Pupulasi Ikan

Gambar 1 juga memperlihatkan bahwa pertumbuhan populasi tidak dimulai pada titik nol, tetapi pada titik $X_{\text {min. }}$. Hanya pada jumlah populasi minimum inilah, populasi ikan akan dapat bertambah, tetapi jika jumlah populasi berada dibawah $\mathrm{X}_{\min }$ maka populasi tidak akan mampu lagi untuk tumbuh bahkan akan terus menurun dan spesies akan mengalami kepunahan. Semakin sedikit jumlah populasi yang masih berada di perairan laut, maka semakin kurang daya regenerasi untuk tumbuh kembali, dan hasil tangkapan ikan juga akan terus menurun. (Moreno \& Majkowski, 2005) melaporkan bahwa 25 persen stok ikan laut dunia telah mengalami overexploitasi, 50 persen telah mencapai pemanfaatan penuh (fully exploitasi), kecenderungan overfishing terjadi secara kontinyu, dan ketersediaan sumberdaya ikan menurun secara kontinyu demikian juga penurunan hasil tangkapan.

\section{Sumberdaya Ikan Milik Bersama.}

Ikan di laut bukan milik seseorang, tetapi milik umum (common property resources), hal ini juga berimplikasi bukan milik siapa-siapa. Pearce dan Turner (1987) menyatakan penting untuk membedakan open access equilibria dan common property equilibria. Pada sumberdaya milik umum, bagai manapun sumberdaya tersebut dimiliki oleh suatu kelompok, suatu komunitas atau suatu Negara, adalah mungkin bahwa anggota atau orang-orang dalam komunitas memiliki akses yang terbuka terhadap sumberdaya tersebut. Disana ada aturan kepemilikan bersama (common property rules) sehingga sumberdaya tersebut dapat tetap eksis.

Sumberdaya milik umum dicirikan dengan, 1) pengambilan dan cara pengambilan tidak dibatasi, setiap individu dalam komunitas dapat mengambilnya, dan 2) terdapat interaksi di antara 
para pemakai sumberdaya itu sehingga terjadi saling berebut satu sama lain dan terjadi eksternalitas disekonomis, karena adanya kesesakan.

Kepunahan dapat terjadi akibat adanya sifat milik bersama ini. Bila perusahaan atau perorangan bebas memasuki suatu bidang usaha tanpa adanya kerja sama, maka masing-masing perusahaan atau perorangan akan mengabaikan biaya alternatif. Keuntungan dari menyimpan sumber daya ikan untuk dipanen pada masa yang akan datang akan hilang. Setiap orang akan berusaha menangkap ikan sebanyak-banyaknya, berbeda jika sumber daya itu dimliki sendiri oleh perusahaan atau perorangan.

Interaksi antara pemakai sumber daya milik umum dapat menyebabkan terjadinya kesesakan (congestion). Dalam kegiatan perikanan tangkap kesesakan ini dapat mempengaruhi produktivitas tangkapan perunit usaha penangkapan atau Cath Per Unit Effort (CPUE), meningkatkan biaya operasional, dan terjadi disefisiensi pada armada tangkap. Dengan kata lain semakin banyak nelayan yang melaut, sehingga melampai suatu batas tertentu akan mengakibatkan inefisiensi dalam industri perikanan tersebut. Inilah sebetulnya inti prediksi model Gordon Schaever bahwa perikanan yang open access akan menimbulkan kondisi economic overfishing. an (Fauzi, 2006).

Inefisiensi dapat ditunjukkan oleh keuntungan nelayan yang kecil akibat biaya penangkapan yang besar dan hasil tangkapan yang sedikit. Bila kemudian sumberdaya ikan dimiliki, maka kesesakan dapat dihindari, dan akan menjadi lebih efisien. Sebagai contoh, nelayan Maine yang memiliki wilayah penangkapan khusus, dan tidak boleh dimasuki oleh nelayan lainnya, maka mempunyai pendapatan yang lebih besar. Seperti dikemukakan oleh (Wilson, 1977) bahwa nelayan Maine yang merupakan anggota gang yang dengan teritori eksklusif mempunyai pendapatan 39\% lebih tinggi, dan hasil tangkapan per trip lebih tinggi 69\% dari nelayan lainnya.

\section{Kurva Penawaran Sumberdaya Perikanan}

Sektor penawaran adalah sektor biaya, karenanya kondisi penawaran harus menggambarkan faktor-faktor biaya. Jadi, kuantitas dari barang tertentu yang ditawarkan merupakan fungsi dari harga barang tersebut, input produksi, keadaan alam, teknologi, pajak dan subsidi. Jika terjadi perubahan dalam salah satu faktor yang mendasari penawaran, maka akan terjadi perubahan dalam penawaran (change in supply), atau terjadi pergesaran kurva penawaran (shiff in supply). Namun, jika terjadi perubahan dalam kuantitas yang ditawarkan, maka pergerakan itu hanya terjadi sepanjang kurva penawaran.

Kemiringan kurva penawaran tidak dapat ditentukan secara pasti, karena kurva penawaran dapat bergerak ke semua arah. Meskipun demikian secara umumnya kita akan mempergunakan kurva penawaran yang naik miring ke kanan yaitu biaya meningkat seiring meningkatnya produksi. Bagi industri dengan biaya konstan maka kurva penawaran akan 
horizontal. Kurva penawaran jangka panjang bagi industry dengan biaya menurun adalah berslope negatif. Kurva penawaran melengkung kebelakang bagi industri yang produksinya tidak dapat ditambah secara terus menerus.

Fungsi penawaran dapat diderivasi dari prilaku produsen dalam proses memaksimumkan laba. Laba (L) diperoleh dari selisih antara penerimaan $(\mathrm{R})$ dengan biaya $(\mathrm{C})$, secara umum dapat di tulis :

$\mathrm{L}(\mathrm{Q})=\mathrm{R}(\mathrm{Q})-\mathrm{c}(\mathrm{Q})$, dimana $\mathrm{R}=\mathrm{PQ}$, Sehingga $\mathrm{L}=\mathrm{PQ}-\mathrm{C}(\mathrm{Q})$.

Fungsi biekonomi yang dikembangkan (Copes, 1972), dengan mengadopsi konsep surplus ekonomi. Copes mengasumsikan bahwa P (harga) tidak konstan, tetapi mengikuti fungsi permintaan yang negatif dan fungsi suplai. Asumsi ini berbeda dengan Gordon yang menganggap harga konstan. Copes melihat pemanfaatan ekonomi sumber daya perikanan untuk optimasi kesejahteraan (welfare optimization), yang diukur melalui analisis surplus konsumen. Penerapan konsep ini, menghasilkan kurva suplai yang melengkung ke belakang pada tingkat output atau tangkapan MSY (back ward bending supply curve). Ini merupakan sumbangan penting dari teori (Copes, 1972). Kurva ini mengisyaratkan bahwa suplai produk perikanan adalah terbatas, sebab faktor ekologi tidak akan mampu terus menerus mendukung produksi.

\section{METODE PENELITIAN}

Perkembangan harga ikan dapat menjadi salah satu indikator sederhana dalam menilai keberlanjutan status eksploitasi. Kurva penawaran prikanan jangka panjang yang melengkung kebelakang (Copes, 1972), dapat digunakan sebagai petunjuk sederhana. (Yagi, Ariji, Takahara, \& Senda, 2009) menggunakan kurva penawaran jangka panjang dalam menilai kondisi sumberdaya ikan, seperti diperlihatkan pada Gambar 2, yang membagi status sumberdaya ikan dalam lima tahap kondisi keberadaan sumberdaya ikan; Pertama, pada keseimbangan awal kurva penawaran jangka pendek $\mathrm{SS}_{1}$ dan kurva permintaan jangka pendek $\mathrm{D}_{1}$ berpotongan pada titik $\left(\mathrm{P}_{1}, \mathrm{Y}_{1}\right)$ dengan ciri jumlah produksi kecil dan harga rendah, ini dinamakan tahap 1 yang merupakan situasi bahwa industri perikanan dioperasikan masih pada kondisi kurang dieksploitasi (underexploited).

Kedua, ketika kurva permintaan bergeser ke $\mathrm{D}_{2}$ dan sisi penawaran bergeser ke $\mathrm{SS}_{2}$ dan keseimbangan pada titik $\left(\mathrm{P}_{1}, \mathrm{Y}_{2}\right)$ yang merupakan produksi pada kondisi Maximum

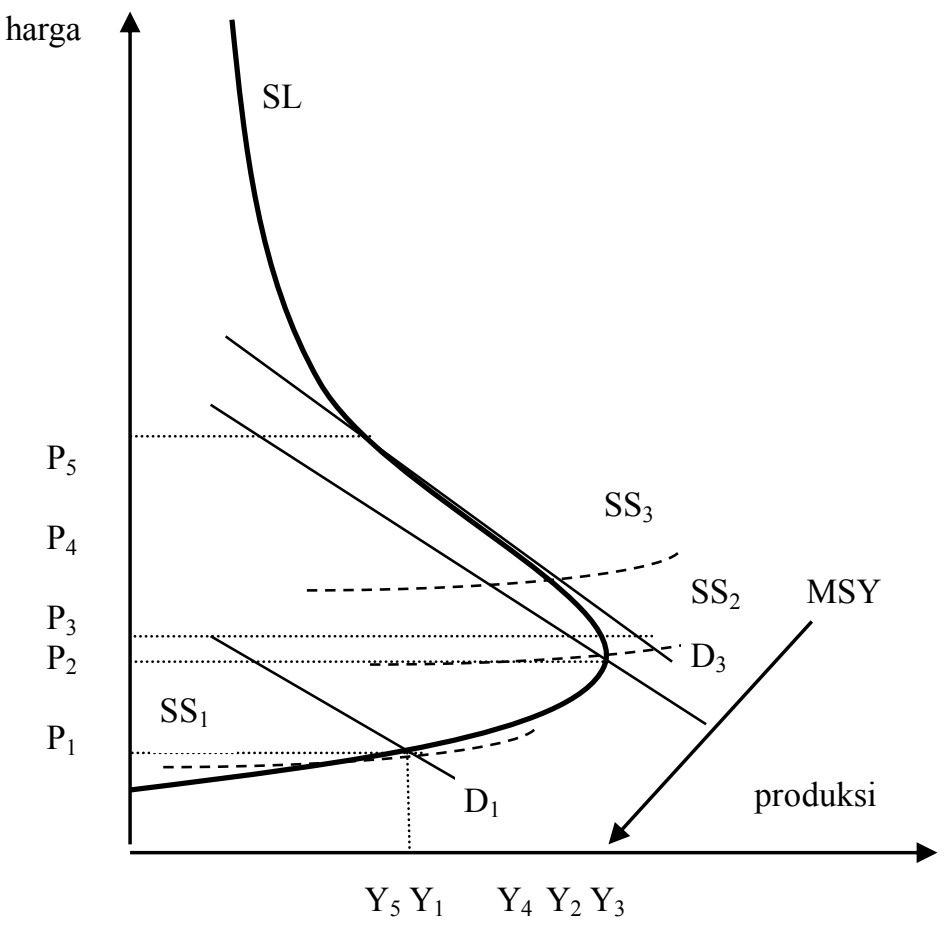




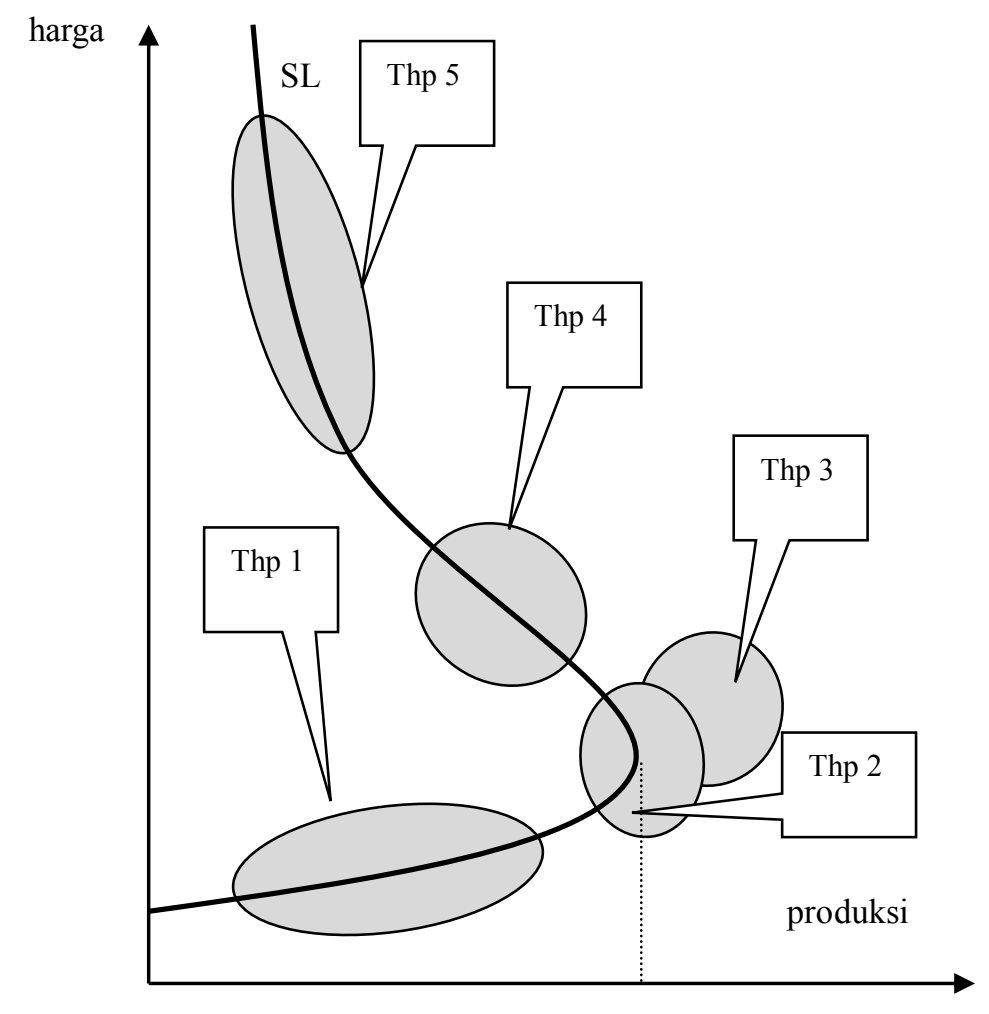

MSY

Gambar 2. Deskripsi Teoritis Status Sumberdaya Ikan pada Perikanan open acces (Yagi, Ariji, Takahara, \& Senda, 2009)

Sustainable Yield (MSY). Ini dinamakan tahap 2, yang ditandai dengan jumlah produksi menengah (moderate) dan harga sedang.

Ketiga, ketika kurva permintaan bergeser ke $\mathrm{D}_{3}$ dan tingkat eksploitasi meningkat dari MSY, maka produksi perikanan pada $\mathrm{Y}_{3}$ dan harga pada $\mathrm{P}_{3}$, ini dinamakan tahap 3 yang merupakan kondisi telah terjadi eksploitasi berlebih, yang mempunyai ciri, jumlah produksi besar dan harga sedang (intermediate). Stok ikan menjadi tidak dapat berlanjut (sustained), dan pertumbuhan stok mulai menurun.

Keempat, ketika penawaran bergeser ke $\mathrm{SS}_{3}$ dan permintaan pada $\mathrm{D}_{3}$ maka keseimbangan pada titik $\left(\mathrm{P}_{4}, \mathrm{Y}_{4}\right)$, ini dinamakan tahap 4 yang mempunyai ciri, jumlah produksi kecil dan harga tinggi adalah kondisi stok telah berkurang (reduced),. Akhirnya, ketika terjadi kelebihan permintaan dan harga menjadi tinggi, kesembangan bergeser pada perpotongan antara kurva SL dan $\mathrm{D}_{3}$ yaitu titik $\left(\mathrm{P}_{5}, \mathrm{Y}_{5}\right)$. Ini disebut tahap 5 dimana kondisi sumberdaya telah terjadi deplisi secara serius dan menuju kepunahan, yang mempunyai ciri, jumlah produksi sangat kecil tetapi harga sangat tinggi.

Metode ini yang diaplikasikan pada perikanan Aceh yaitu pada Wilayah Pengelolaan Perikanan 571 (WPP 571) Selat Malaka dan WPP 572 Samudera Hindia. Data yang digunakan adalah data deret waktu selama periode 27 tahun dari 1989 - 2015. Data yang digunakan adalah data yang dipublikasikan Dinas Perikanan dan Kelautan (DKP) Aceh.

\section{HASIL DAN PEMBAHASAN}

\section{Perikanan Selat Malaka}

Plot antara produksi dan harga dengan menggunakan data 27 tahun, pada WPP 571 yaitu perairan Selat Malaka, dapat dilihat pada Gambar 3. Periode taun 1989-1998 produksi perikanan terlihat rendah dan harga juga relative rendah. Hal ini berarti wilayah perikanan Selat Malaka Aceh masih dioperasikan pada posisi kurang dieksploitasi. Pada periode tahun 1999 2006 kelihatannya perikanan dieksploitasikan pada level MSY, yang ditandai dengan harga cenderung sedang dan produksi menengah.

Sedangkan pada tahun 2007 - 2015 terlihat arah kurva mulai meningkat dan cenderung melengkung. Jumlah produksi meningkat lebih lambat sementara harga cenderung meningkat lebih cepat. Indikasi ini memperlihatkan bahwa ada kecenderungan perikanan dioperasikan pada 
tingkat kelebihan eksploitasi (tahap ketiga), pada kondisi ini stok ikan masih mengalami pertumbuhan, namun pada level yang mulai menurun. Kondisi ini jika dibiarkan dapat terus berlanjut dan dapat mengancam kelestarian sumberdaya perikanan..

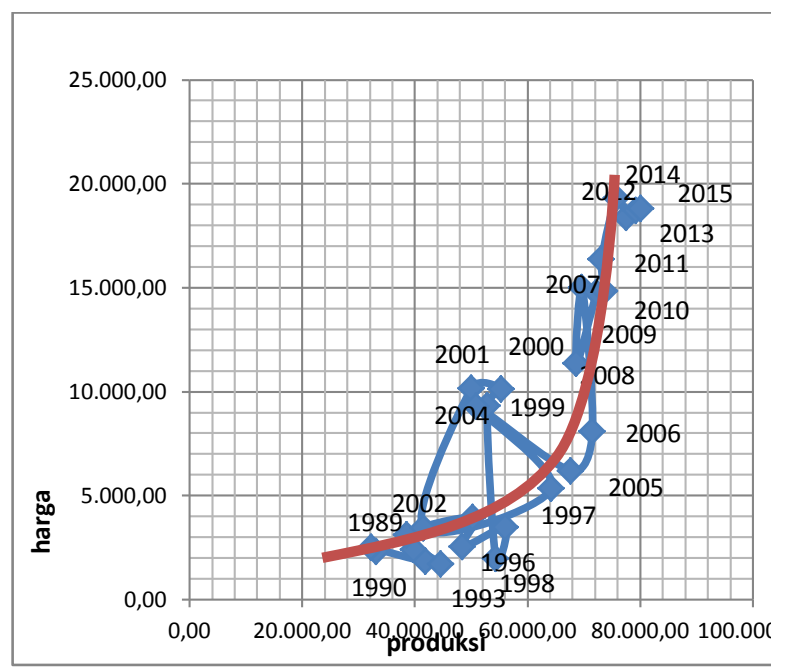

Gambar 3. Grafik Harga dan Produksi Perikanan Selat Malaka (1989 - 2015)

\section{Perikanan Samudera Hindia}

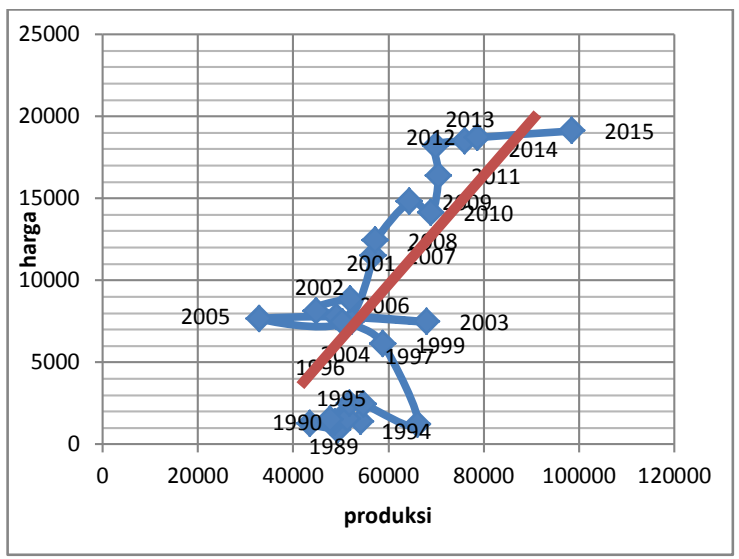

Gambar 4. Grafik Harga dan Produksi Perikanan Samudera Hindia (1989 - 2015)

Grafik hubungan harga dengan produksi pada WPP 572 yaitu wilayah perikanan Samudera Hindia disajikan pada Gambar 4. Selama periode analisis 1989- 2017, grafik penawaran jangka panjang terlihat miring kekanan, sebagaimana grafik penawaran pada umumnya. Belum terlihat adanya grafik yang melengkung, ini mengindikasikan bahwa perikanan Samudera Hindia dioperasikan pada tahap 1 yaitu kurang dieksploitasi.

\section{Pembahasan}

Temuan status eksploitasi Selat Malaka konsisten dengan laporan Direktorat Jenderal Perikanan Tangkap Dinas Kelautan dan Perikanan tahun 2005 bahwa pada wilayah pengelolaan perikanan Selat Malaka secara umum sumberdaya ikan pelagis, ikan demersal dan ikan karang, semuanya telah kelebihan eksploitasi, dalam (Mallawa, 2006). (Indra, 2007) juga melaporkan bahwa perikanan Selat Malaka Aceh telah dioperasikan di atas MSY, demikian juga laporan. (Asmawati \& Nazamuddin, 2013)

Jika dikaitkan dengan jumlah armada perikanan yang beroperasi di wilayah perikanan Selat Malaka, pada periode tahun 1989 - 1998 menunjukkan bahwa armada perikanan lebih didominasi oleh motor tempel dan perahu. Sedangkan pada periode tahun 1999-2017 didominasi oleh kapal motor ukuran 5 GT atau lebih kecil, yang jumlahnya mencapai $85 \%$. Kapal motor ukuran 5 GT yang mendapatkan izin pengoperasian dari pemerintah Kabupaten dan beroperasi pada wilayah 4 mil laut. Hal ini, memungkinkan bahwa kinerja perikanan Selat Malaka yang telah kelebihan eksploitasi (over exploited) adalah pada wilayah perikanan dekat pantai. Dalam hal ini, (Garces, et al., 2006), memperingatkan bahwa, penggunaan boat kecil yang lebih banyak, memungkinkan terjadi 
kelebihan tangkap (overfishing) pada area dekat pantai dan dapat mengancam keberlanjutan sumberdaya perikanan.

Status eksploitasi yang ditemukan pada perikanan Samudera Hindia, hampir sejalan dengan laporan DKP pada tahun 2005 bahwa sumberdaya ikan pelagis masih kurang dieksploitasi, tetapi sumberdaya ikan demersal, dan ikan karang telah dieksploitasi berlebih, dalam (Mallawa, 2006).

Pada wilayah perikanan Samudera Hindia ini, jumlah nelayan yang beroperasi dengan armada perahu, motor tempel dan kapal motor $\leq$ 5 GT mencapai $89 \%$. Hal ini memperkuat indikasi bahwa perikanan Samudera Hindia masih kurang dieksploitasi, terutama daerah di luar jangkauan kapal motor 5 GT. Bahkan DKP mengkalianm produksi perikanan Aceh baru 57\% dari potensi MSY. Artinya masih banyak sumberdaya ikan yang belum dimanfaatkan untuk kesejahteraan masyarakat. Bahkan sering kita dengar kapal asing mencuri ikan di laut teritori Aceh

\section{KESIMPULAN DAN SARAN}

\section{Kesimpulan}

Status pemanfaatan sumberdaya perikanan Aceh, WPP 571 Selat Malaka telah dioperasikan pada posisi awal di atas MSY atau kelebihan eksploitasi. Sedangkan WPP 572 Samudera Hindia dioperasikan di bawah MSY atau kurang dieksploitasi.

Saran

Kapasitas perikanan pada perikanan Samudera Hindia masih dapat ditingkatkan untuk kesejahteraan masyarakat. Terutama harus fokus pada armada kapal motor ukuran diatas 10 GT. Sedangkan pada perikanan Selat Malaka, sebaiknya tidak menambah armada perikanan. Jika ingin ditambah tentu kapal ukuran 30 GT.

Pengelola perikanan atau pemerintah perlu memastikan cara penangkapan dan ukuran mata jaring, dan menetapkan daerah daerah konservasi.

\section{DAFTAR PUSTAKA}

Agus, A., Arifin, S., \& Harjito, D. A. (2008). Model Kebijakan Pemberdayaan Nelayan Bantul Ditinjau Dari Perspektif Ekonomi dan Hukum . Jurnal Fenomena Vol 6 No 1 , Didektorat Penelitian dan Pengabdian pada Masyarakat, Universitas Islam Indonesia (UII) Yogyakarta.

Asmawati, \& Nazamuddin. (2013). Disequilibrium Pasar Ikan Laut Aceh. Jurnal Ekonomi Pembangunan Vol 14, 38-51.

Be'Ne', C., Arthur, R., Norbury, H., Allison, E. H., Beveridge, M., Bush, S., et al. (2016). Contribution of Fisheries and Aquaculture to Food Security and Poverty Reduction: Assessing the Current Evidence. World Development Vol. 79, , 177-196.

Bischi, G., Kopel, M., \& Szidarovszky, F. (2005). Exspetation-Stok Dynamics in Multi Agent Fisheries. Springer Science + Business Media,Inc Manufactured in Nedherlands .

Briones, R., Garces, L., \& Ahmed, M. (2005). Climate Change and Small 
Pelagic Fisheries in Developing Asia:

The Economic Impact on Fish

Producers and Consumers. Dalam H.

Text, Climate Change and The

Economics of World's Fisheries (hal. 215-235).

BRR. (2005). Aceh and Nias One Year After Tsunami; The Recovery Effort and Way Forward. A Joint Report of BRR and international partners. Aceh Nias Rehabilitation and Reconstruction Agency; 205 pp.

Copes, P. (1972). Factor Rents Soleownership and the Optimum Level of Fisheries Exploitation. Manchester Shool Econ Soc Studies Vol 49 No 2 , 145-163.

Fauzi, A. (2006). Ekonomi Sumberdaya Alam dan Lingkungan (teori dan aplikasi). Jakarta: PT Gramedia Pustaka Utama.

Garces, L., Tewtik, A., Pido, M., Fatan, N., Adhuri, D., Andrew, N., et al. (2006). Fisheries Rehabilitation in PostTsunami Aceh: Status and Needs From Participatory Appraisals. NAGA Worldfish Center Quarterly Vol 29 , 19-30.

Indra. (2007). Model Bio-Ekonomi Opsi Rehabilitasi Sumberdaya Perikanan di Provinsi Nanggroe Aceh Darussalam. Disertasi Doktor Sekolah Pasca Sarjana Institut Pertanian Bogor. Tidak dipublikasikan.

Kelautan, D. J. (2006). Pedoman Jenis-jenis Penangkapan Ikan yang Ramah
Lingkungan. Volume 1. Departemen Kelautan dan Perikanan.

Mallawa, A. (2006). Pengelolaan Sumberdaya Ikan Berkelanjutan dan Berbasis Masyarakat. Lokakarya Agenda Penelitian COREMAP II Kabupaten Selayar.

Moreno, L., \& Majkowski, J. (2005). Status of the Tuna Stocks of the World. FAO Fish .

Muchaponwa, E. (2009). Supply Response of Zimbabwean Agriculture: 1970-1999. Afjare Vol 3 No 1 Shool of Economic University of Cape Town , 27-42.

Nahib, I. (2007). Analisis Dinamik Sumberdaya Perikanan Tuna Kecil : Studi kasus di perairan teluk Pelabuhanratu Kabupaten Sukabumi. Proceeding Geo Matenr Research Forum .

Pearce, D. W., \& Turner, R. K. (1987). Economisc of Natural Resources and The Environment. the Johns Hopkins University Press Baltimore.

Tewfik, A., Andrew, N., Bene, C., \& Garces, L. (2008). Reconciling Poverty Alleviation With Reduction in Fisheries Capacity: boat aid posttsunami Aceh. Fisheries Management \& Ekology, vol 15, 147-158.

Walters, C., \& Maguire, J. (1996). Lesson for Stok Assessment from the Northern Cod Collapse. Reviews in Fish Biologi and Fisheries 6 .

Wilson, J. (1977). A Tes of Tragedi of the 
Jurnal Humaniora, 1(2), 109-118

Oktober 2017

http://jurnal.abulyatama.ac.id/humaniora

Commons. Dalam G. H. Braden,

Managing the Commons. San

Fransisco: Freeman.

Yagi, N., Ariji, M., Takahara, A., \& Senda, Y.

(2009). Application of a Bioeconomics

Model to Examine Sustainability of

Fishery Resources in the Global

Market: the case of octopus resource in

Morocco. Fish Chi, Springer, Japan,

43-46 